\title{
RANCANG BANGUN SISTEM INFORMASI PENGOLAHAN DATA PASIEN BERBASIS DESKTOP PADA KLINIK PRATAMA SUMBER ASI BOGOR
}

\author{
Nuriana Khusnul Khotimah ${ }^{1}$, Forkas Tiroy Santos B. ${ }^{2}$, Irawan Setiadi ${ }^{3}$ \\ ${ }^{1,2,3}$ Teknik Informatika, FTIK, Universitas Indraprasta PGRI \\ Jalan Raya Tengah No 80, Kelurahan Gedong, Pasar Rebo, Jakarta Timur \\ 1'nurianakhusnulkhotimah@gmail.com, ${ }^{2}$ ftsb43dharma@gmail.com, ${ }^{3}$ irawan.setiadi91@gmail.com
}

\begin{abstract}
ABSTRAK
Klinik Pratama Sumber Asi merupakan tempat pelayanan kesehatan masyarakat yang berada di Gunung Putri, Bogor. Klinik ini dalam pengolahan data pasiennya masih menggunakan sistem konvensional, seperti saat proses pendaftaran pasien, menulis rekam medis, serta pembayarannya, sehingga rawan akan terjadinya kesalahan atau kekeliruan dalam pengolahan data, serta saat melakukan pencarian data pasien yang hendak dibutuhkan, petugas mengalami kesulitan dalam mencarinya dalam buku - buku arsip. Proses yang berjalan ini dirasa sangat tidak efisien. Oleh karena itu, tujuan dari penelitian adalah untuk menggantikan sistem pengolahan data pasien yang masih secara konvensional menjadi sistem yang terkomputerisasi untuk mengurangi terjadinya kesalahan atau kekeliruan dalam pengolahan data. Metode penelitian yang digunakan yaitu metode analisis data, wawancara, observasi lapangan dan menggunakan metode grounded (grounded research), dengan java dan MySQL. Metode pengembangan yang dipakai adalah metode waterfall. Dari permasalahan yang ada dapat ditarik kesimpulan bahwa hasil dari penelitian ini yaitu berupa sistem informasi berbasis desktop yang dapat digunakan untuk proses pengolahan data secara komputerisasi agar saat melakukan penginputan data dapat terhindar dari kesalahan atau kekeliruan, dan saat hendak melakukan pencarian data dapat dilakukan dengan mudah, hanya tinggal memasukkan nama atau kode data yang hendak dicari.
\end{abstract}

Kata Kunci: Sistem Informasi, Pengolahan Data Pasien, Desktop

\section{ABSTRACT}

Pratama Sumber Asi Clinic is a community health service located in Gunung Putri, Bogor. This clinic in processing patient data still uses conventional systems, such as during the patient registration process, writing medical records, and payments, so it is prone to errors in data processing, and when searching for patient data, officers have difficulty finding it in archival books. This process is considered very inefficient. Therefore, the purpose of the research is to replace the conventional patient data processing system into a computerized system to reduce the occurrence of errors in data processing. The research method used is data analysis, interviews, field observations and using the grounded method (grounded research), with java and MYSQL. The development method used is the waterfall method. From the existing problems, it can be concluded that the results of this research are in the form of a desktop-based information system that can be used for computerized data processing so that when input data it can avoid errors or mistakes, and when trying to search data it can be done easily, just enter the name or code of the data you want to find.

Key Word: Information Systems, Patient Data Processing, Desktop

\section{PENDAHULUAN}

Perkembangan teknologi dan informasi di zaman sekarang ini tentunya tidak dapat dipungkiri lagi kemajuannya. Banyak instansi sudah beralih dari sistem konvensional menjadi sistem informasi yang sudah terkomputerisasi. Adanya sistem informasi ini menjadikan pengolahan data dan informasi menjadi lebih optimal dan efisien. Seperti di bidang perkantoran maupun bidang kesehatan seperti klinik, dengan adanya sistem informasi yang terkomputerisasi ini dapat memudahkan petugas klinik dalam mengelola data pasien, data pemeriksaan, transaksi serta dalam pembuatan laporan.

Pada Klinik Pratama Sumber Asi sistem yang dipakai saat pendaftaran pasien serta rekam medis masih dilakukan secara konvensional begitu juga dengan proses pembayaran biaya pemeriksaan serta pembuatan nota masih dilakukan secara konvensional, sehingga dapat mengakibatkan terjadinya kesalahan perhitungan maupun kesalahan dalam pengolahan data. Proses yang berjalan ini 
dirasa sangat kurang efisien, karena petugas klinik sering menemukan hambatan dalam melakukan pencarian data pasien saat hendak dibutuhkan dimana data pasien yang ada cukup banyak. Oleh karena itu, dengan adanya sistem informasi pengolahan data pasien ini diharapkan dapat mengatasi permasalahan yang terjadi selama ini.

Rancang Bangun merupakan suatu istilah umum dalam membuat atau mendesain objek mulai dari awal pembuatan sampai akhir proses pembuatannya (Prasetya, $2020: 159$ ).

Sistem merupakan suatu rangkaian komponen yang saling terhubung dan saling berinteraksi untuk mencapai tujuan tertentu. Biasanya suatu sistem terdiri dari subsistem yang lebih kecil yang mendukung sistem yang lebih besar (Asrori dan Nuryani, 2020 : 17).

Informasi merupakan hasil akhir dari data yang sudah diproses dalam suatu sistem sehingga menjadi bentuk yang lebih berguna bagi penerima untuk menentukan suatu keputusan tertentu (Haryanto dan Firmansyah, 2018 : 156).

Sistem informasi dapat diartikan sebagai seperangkat entitas yang terdiri dari hardware, brainware dan software yang saling bekerjasama untuk menyediakan data yang diolah sehingga memberikan banyak manfaat bagi yang menerima data tersebut (Herliana dan Rasyid, 2016 : 43).

Data merupakan bahan mentah yang diolah dan kemudian hasilnya menjadi suatu informasi. Dengan demikian data yang diperoleh harus diukur dan dinilai berguna atau tidak, baik atau buruk dalam hubungannya dengan tujuan yang hendak dicapai. Pengolahan data dapat dibagi menjadi dua kegiatan, yaitu kegiatan penyimpanan data dan kegiatan penanganan data (Sutabri, $2012: 6$ ).

Pasien ialah seseorang yang memerlukan jasa pelayanan kesehatan dari orang lain, dimana dokter sebagai konsultan masalah kesehatannya, baik itu dilakukan secara langsung maupun tidak langsung (Haryanto dan Firmansyah, 2018 : 157).

Tujuan dari penelitian ini ialah untuk mempermudah serta mempercepat kinerja dalam pengolahan data pasien pada Klinik Pratama Sumber Asi.

Manfaat yang didapat dari penelitian ini bagi instansi yaitu dapat mempermudah petugas klinik dalam melakukan proses pengolahan data pasien serta menjadikan pengolahan data pasien agar lebih efektif dan efisien. Manfaat bagi penulis yaitu dapat memperoleh pemahaman mengenai rancang bangun sistem infotmasi pengolahan data pasien.

\section{METODE PENELITIAN}

Metode penelitian yang dipakai oleh penulis dalam penelitian ini yaitu metode grounded (grounded research), yaitu suatu metode penelitian yang berdasarkan dengan fakta dan menggunakan analisis komparatif yang bertujuan untuk mengadakan generalisasi empiris, menetapkan konsep, membuktikan serta mengembangkan teori, mengumpulkan dan menganalisis data dalam waktu serentak (Syahputra dkk., 2021: 544 ).

Dalam penelitian ini data merupakan sumber teori. Adapun langkah-langkah yang digunakan dalam metode ini adalah menentukan masalah yang akan diselidiki, mengumpulkan data-data di lapangan, menganalisis dan mendeskripsikan masalah yang ditemukan serta membuat hasil penelitiannya.

\section{Metode Pengumpulan Data}

1. Studi pustaka

Pengumpulan data dilakukan dengan cara mempelajari buku, jurnal serta informasi yang berhubungan dengan masalah pengolahan data pasien pada klinik.

2. Studi Lapangan

\section{a. Observasi}

Metode observasi ini dilakukan dengan melakukan pengamatan secara langsung di lapangan mengenai pengolahan data pasien di klinik.

b. Wawancara

Wawancara ini dilakukan untuk memperoleh data dari Ibu Deni Wiryati,S.SiT selaku pimpinan di Klinik Pratama Sumber Asi. Dalam penelitian ini, peneliti menanyakan beberapa hal terkait dengan sistem pengolahan data pasien secara konvensional yang digunakan sebelumnya di Klinik Pratama Sumber Asi. Metode ini digunakan untuk 
memperoleh informasi dan data statistik pada Klinik Pratama Sumber Asi.

Langkah - langkah pengembangan sistem:

Dalam pengembangan sistem informasi dalam pengolahan data pasien di Klinik Pratama Sumber Asi, metode yang digunakan yaitu metode waterfall yang di mana waterfall atau air terjun adalah model yang digunakan untuk mengembangkan maupun membuat perangkat lunak, serta model berkembang secara sistematis dari satu tahap ke tahap lain dalam metode seperti air terjun. Model ini mengusulkan pendekatan pengembangan software yang sistematis dan berurutan mulai dari tingkat kemajuan sistem pada proses analisis, desain, kode, pengujian dan pemeliharaan. (Wijaya dan Astuti, 2019)

Tahap-tahap pengembangan model waterfall adalah sebagai berikut :

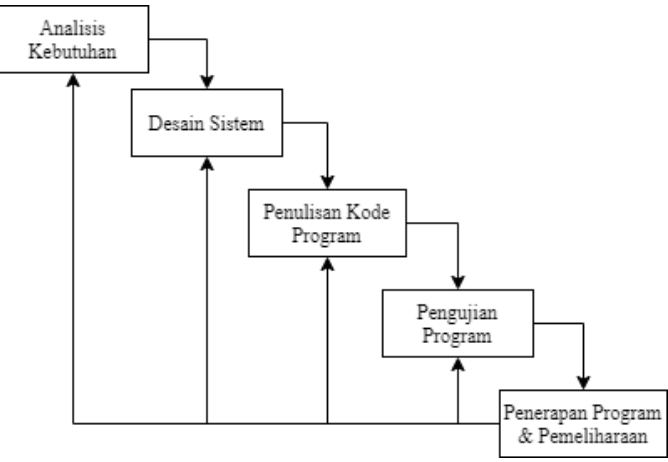

Gambar 1. Metode Waterfall

\section{Analisis Kebutuhan (Requirement)}

Proses analisis kebutuhan ini dapat dilakukan dengan pengumpulan data, yang dapat berupa observasi, wawancara atau studi pustaka.

2.Desain Sistem (Design)

Tahapan dimana pemikiran dan perancangan sistem dituangkan ke dalam solusi permasalahan yang ada dengan menggunakan alat pemodelan sistem seperti DFD (Data Flow Diagram).

3.Penulisan Kode Program (Implementation) Merupakan penerjemahanan suatu perintah ke dalam bahasa yang dapat dikenali oleh komputer.

4. Pengujian Sistem (Verification)

Tahap terakhir dimana sistem baru diuji

kemampuan dan efektivitasnya

5. Penerapan Program dan Pemeliharaan
Program yang sudah diberikan ke pelanggan pasti akan terjadi perubahan. Perubahan tersebut dapat terjadi karena kesalahan yang disebabkan oleh program yang harus beradaptasi dengan lingkungan baru atau komputer yang berbeda, serta bisa jadi karena pelanggan membutuhkan pengembangan fungsional.

\section{HASIL DAN PEMBAHASAN}

Berdasarkan dari permasalahan sistem pengolahan data pasien yang ada pada Klinik Pratama Sumber Asi tersebut, maka dapat diusulkan beberapa alternatif dalam penyelesaian masalahnya, yaitu:

1. Pembuatan Sistem Informasi Pengolahan Data Pasien yang terkomputerisasi dan terhubung dengan database, sehingga dapat berjalan lebih efektif dan efisien.

2. Pengolahan data pasien yang terkoneksi database dapat mencegah kekeliruan atau kesalahan dalam penyimpanan datanya, serta dapat mengurangi kemungkinan kehilangan data, dan dapat lebih mudah dalam pencarian data.

3. Pembuatan laporan yang otomatis dan sistematis derdasarkan database agar lebih mudah dan cepat dalam pembuatannya

Berikut adalah gambaran sistem yang diusulkan untuk Klinik Pratama Sumber Asi:

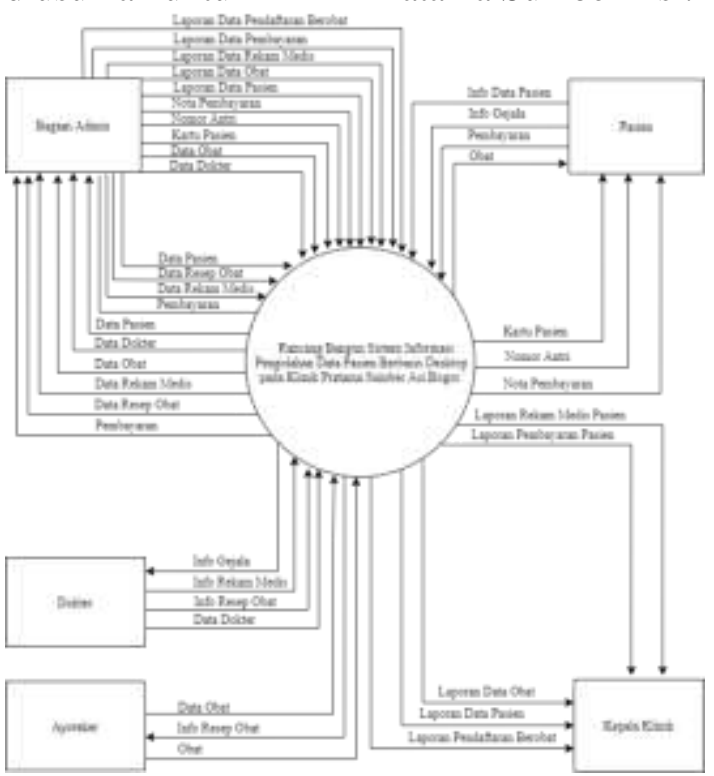

Gambar 2. Diagram Konteks yang Diusulkan

Entitiy Relationship Diagram (ERD) merupakan model awal basis data yang akan dikembangkan berdasarkan teori himpunan 
dalam matematika untuk pemodelan basis data relasional (Sukamto dan Shalahuddin, $2015: 289$ )

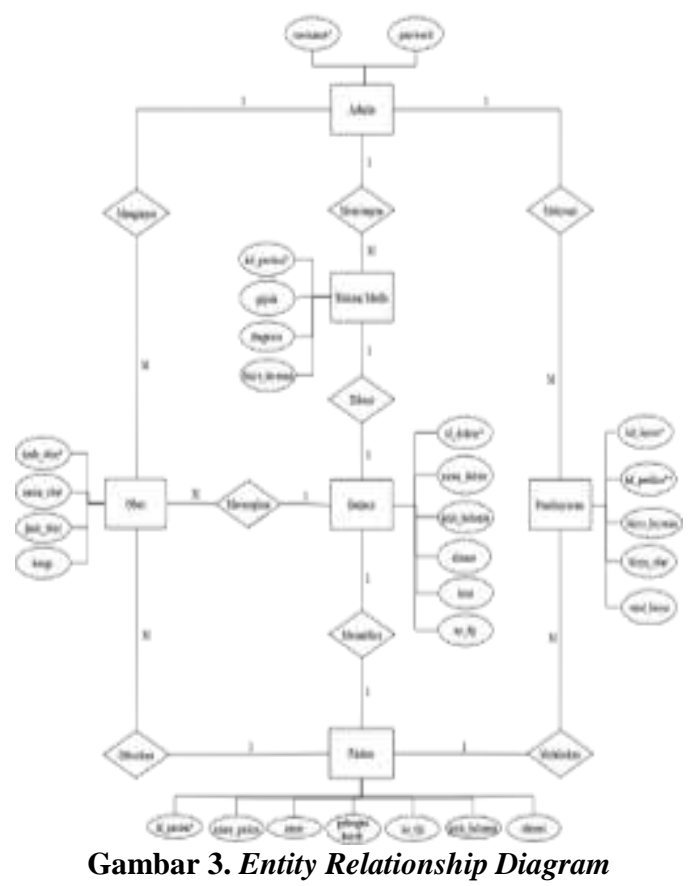

Adapun di bawah ini adalah tampilan layar login, menu utama, data dokter, data pasien, data obat, data pendaftaran, data pemeriksaan, data pembayaran serta laporan yang yang ditampilkan dalam pengujian program adalah sebagai berikut:

\section{Tampilan Login}

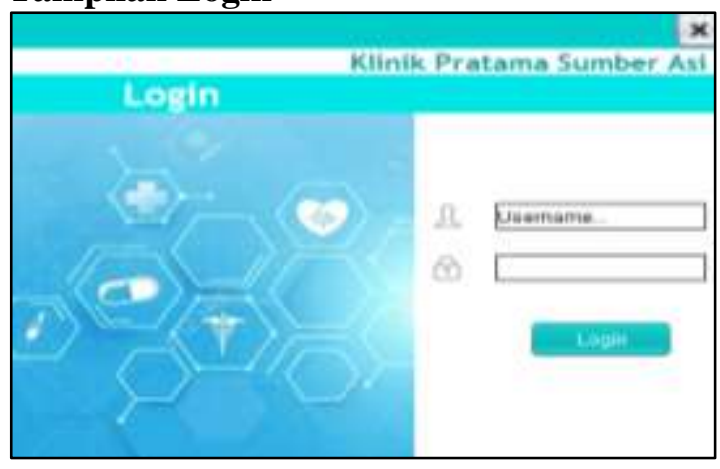

Gambar 4. Tampilan Login

Tampilan Login ini akan muncul pertama kali saat program dijalankan, berfungsi sebagai kata kunci sebelum kita memasuki program utama. Terdapat username dan password yang dapat diisi terlebih dahulu oleh admin atau orang yang memiliki akses. Sehingga kerahasian datanya terjaga dengan baik.
Tampilan Menu Utama

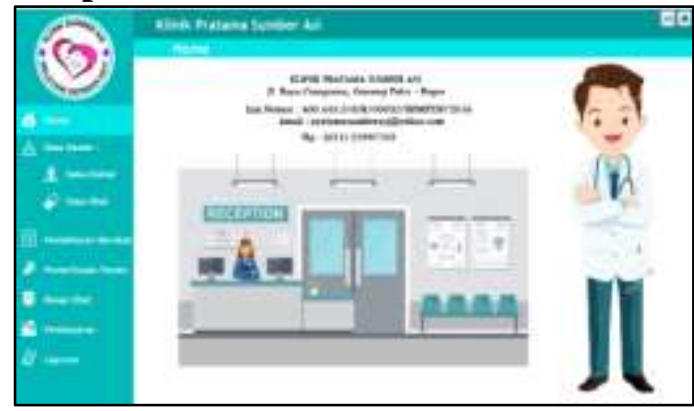

Gambar 5. Tampilan Menu Utama

Pada menu utama ini tersedia menu bar yaitu menu Home, Form Data Dokter, Data Obat, Pendaftaran Berobat, Pemeriksaan Pasien, Resep Obat, Pembayaran, dan Laporan. Kemudian pada layar menu utama terdapat alamat serta data Klinik Pratama Sumber Asi serta terdapat gambar animasi di sisinya

\section{Tampilan Data Dokter}

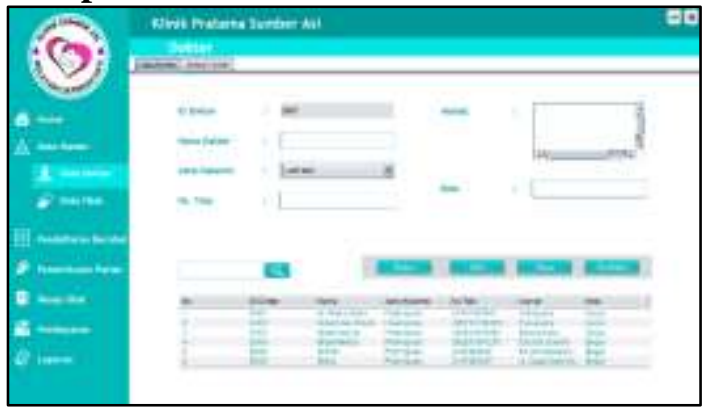

Gambar 6. Tampilan Data Dokter

Pada form data dokter ini admin dapat melakukan pengisian data seperti id dokter, nama dokter, jenis kelamin, no telp, alamat dan kota. Di dalam form ini admin dapat melakukan penyimpanan data dengan mengisikan data diri dokter terlebih dahulu kemudian klik simpan, serta dapat melakukan update data yang sudah tersimpan dengan menekan tombol perbarui, dan dapat menghapus data dengan menekan tombol hapus.

Tampilan Data Obat

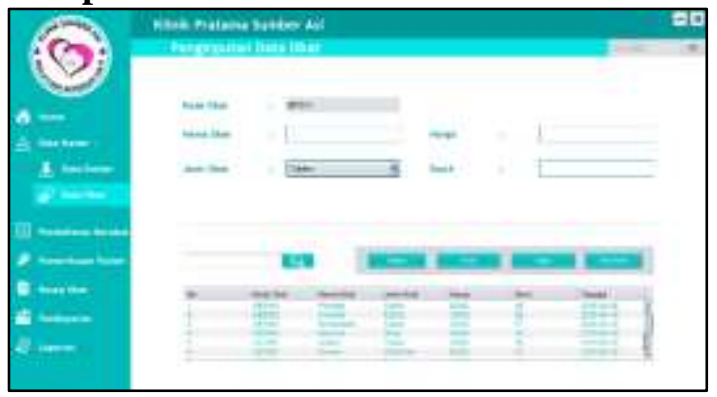

Gambar 7. Tampilan Data Obat 
Pada form data obat ini admin dapat melakukan pengisian data seperti kode obat, nama obat, jenis obat, kategori obat, harga dan stock obat. Setelah melakukan pengisian data obat kemudian tekan tombol simpan agar data tersimpan ke dalam database. Selain itu untuk memperbarui jumlah stock obat atau data obat lainnya dapat dilakukan dengan klik tombol perbarui. Dan apabila hendak menghapus data obat yang sudah tidak dipakai dapat menekan tombol hapus.

\section{Tampilan Data Pasien}

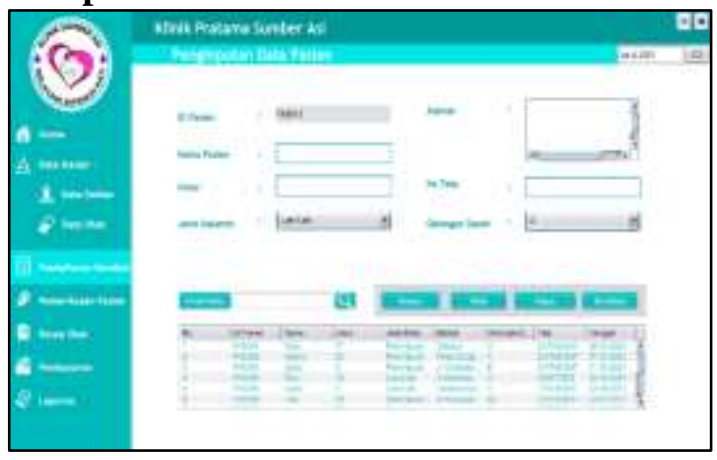

Gambar 8. Tampilan Data Pasien

Form data pasien ini berfungsi untuk memasukkan data pasien yang baru pertama kali datang ke klinik, sehingga pasien harus mengisi data diri pasien terlebih dahulu yang dimasukkan oleh admin seperti id pasien, nama pasien, umur, jenis kelamin, alamat, no telp dan golongan darah. Kemudian data tersebut disimpan ke dalam database, sehingga apabila pasien hendak kembali ke klinik datanya sudah tersimpan.

\section{Tampilan Data Pendaftaran Berobat}

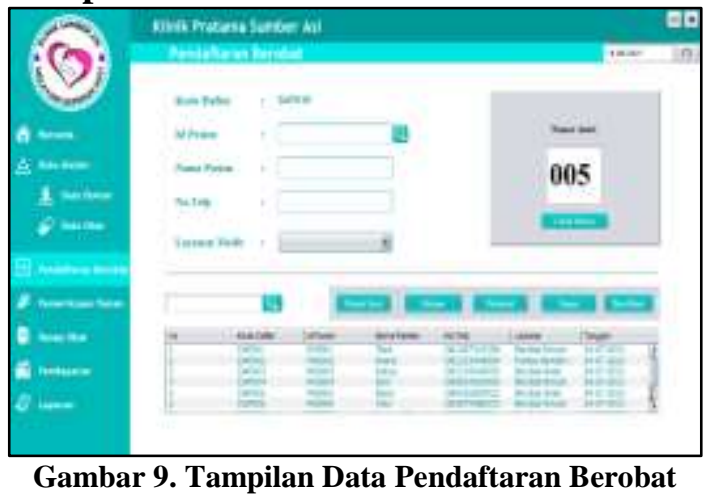

Form pendaftaran berobat ini digunakan untuk mendata pasien yang hendak mendaftar untuk melakukan pengobatan di klinik. Di form ini terdapat kode daftar, serta dapat memanggil data id pasien yang sudah masuk ke dalam database pasien karena telah melakukan registrasi sebagai pasien klinik, sehingga akan muncul nama pasien, no telp secara otomatis kemudian terdapat pilihan layanan medis.

\section{Tampilan Pemeriksaan}

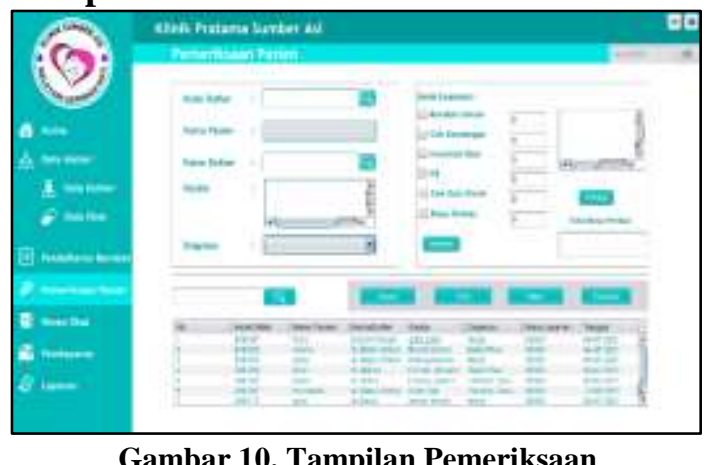

Form pemeriksaan ini berfungsi untuk melakukan pengisian data periksa pasien, yang di dalamnya terdapat nomor daftar yang dapat digunakan untuk memanggil nama pasien berdasarkan dengan nomor daftarnya, kemudian nama dokter yang menangani pasien, kemudian input gejala, diagnosa, serta jenis layanan untuk. Kemudian terdapat total biaya periksa dari jenis layanan yang diberikan kepada pasien.

\section{Tampilan Resep Obat}

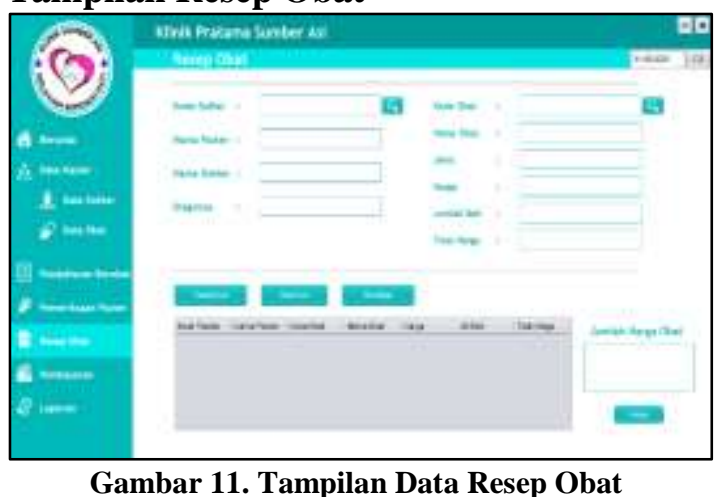

Form resep obat ini digunakan untuk memasukkan data resep obat. Terdapat kode daftar yang digunakan untuk memanggil data pasien dari proses sebelumnya yang berisi kode daftar, nama pasien, dan nama dokter. Kemudian diberikan resep obat oleh dokter yang menanganinya. Lalu admin input data obat yang sudah di berikan oleh dokter yaitu: nama obat, jenis obat, harga, jumlah beli, dan total harga. Terdapat tombol tambah list yang berfungsi memasukkan atau menyimpan resep obat yang akan diberikan kepada pasien. Serta 
terdapat tombol batal list untuk membatalkan obat yang dipilih.

\section{Tampilan Pembayaran}

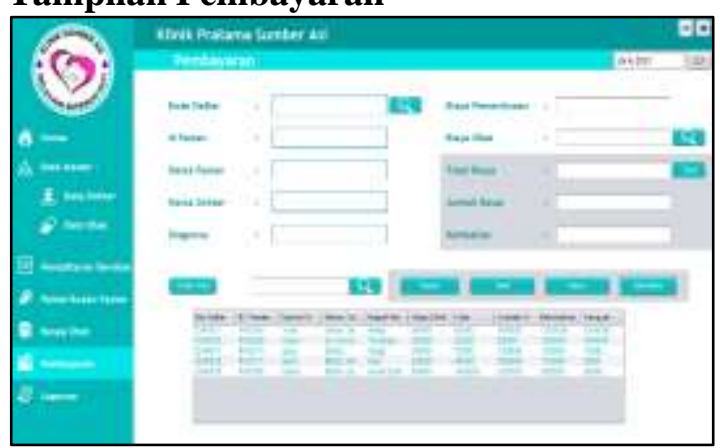

Gambar 12. Tampilan Pembayaran

Tampilan form pembayaran ini digunakan untuk input data pembayaran pasien, Terdiri dari kode daftar yang otomatis dapat memanggil id pasien, nama pasien, nama dokter, diagnosa, biaya pemeriksaan, serta biaya obat, setelah itu dijumlahkan menjadi total biaya, kemudian pasien membayar biaya berobat lalu admin input jumlah bayar, kemudian akan otomatis keluar info jumlah kembalian.

\section{Tampilan Laporan Data Pasien}

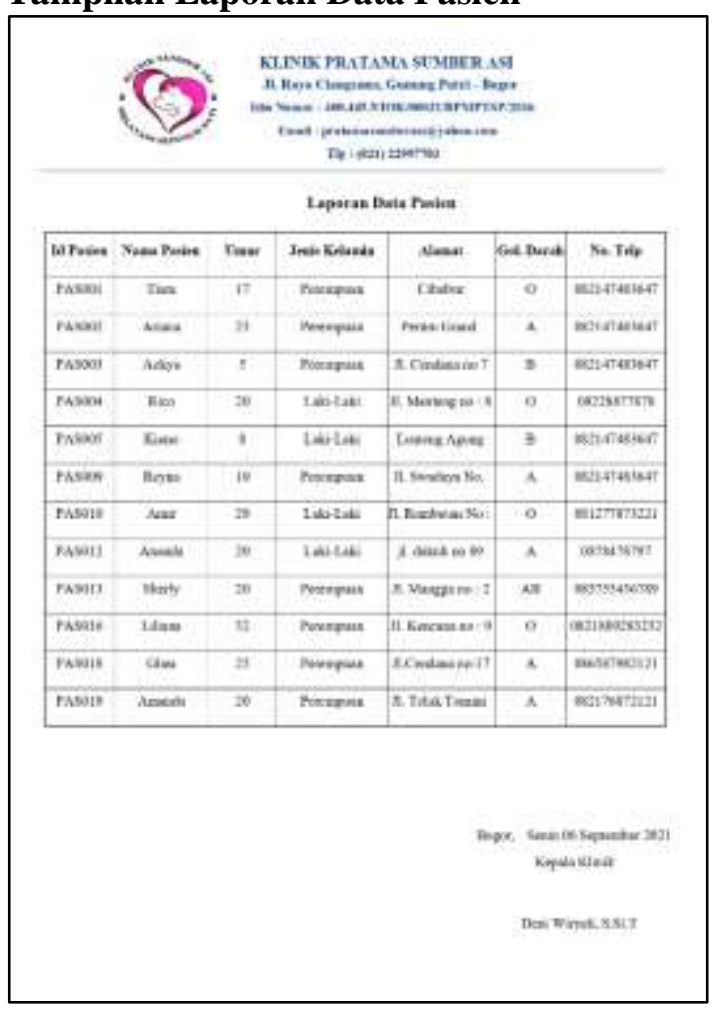

Gambar 13. Tampilan Laporan Data Pasien

Pada tampilan laporan pasien berisi id pasien, nama pasien, umur, jenis kelamin, alamat, golongan darah, dan no telp. Laporan ini didapat dari data pasien yang tersimpan ke dalam database.

\section{Tampilan Laporan Data Obat}

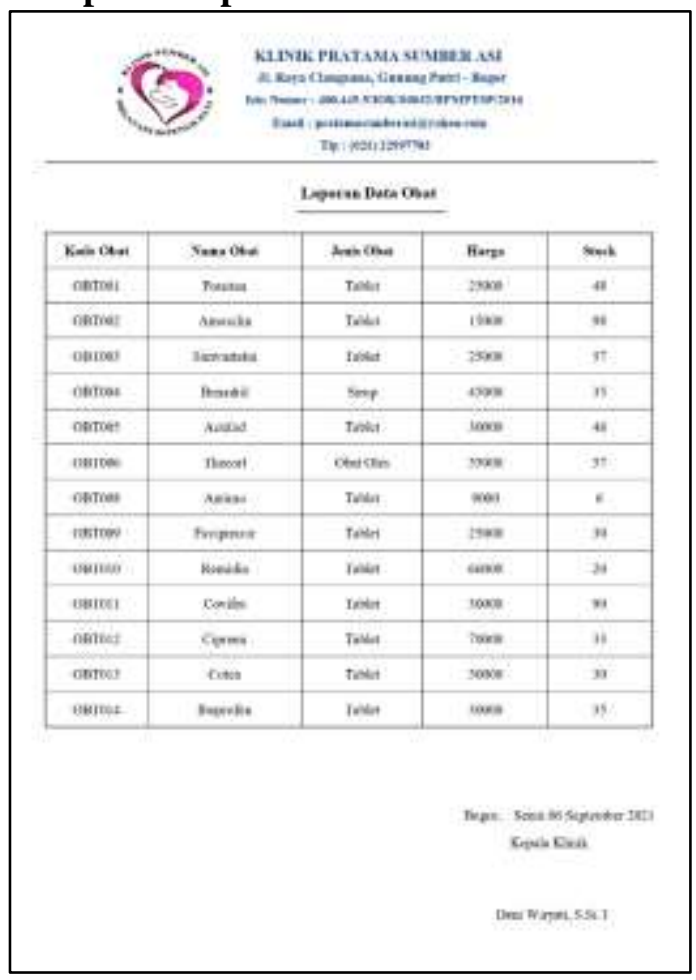

Gambar 14. Tampilan Laporan Data Obat

Pada tampilan laporan data obat berisi kode obat, nama obat, jenis obat, harga obat, dan stock. Laporan data obat didapat dari data obat yang tersimpan ke dalam database.

\section{Tampilan Laporan Data Pembayaran}

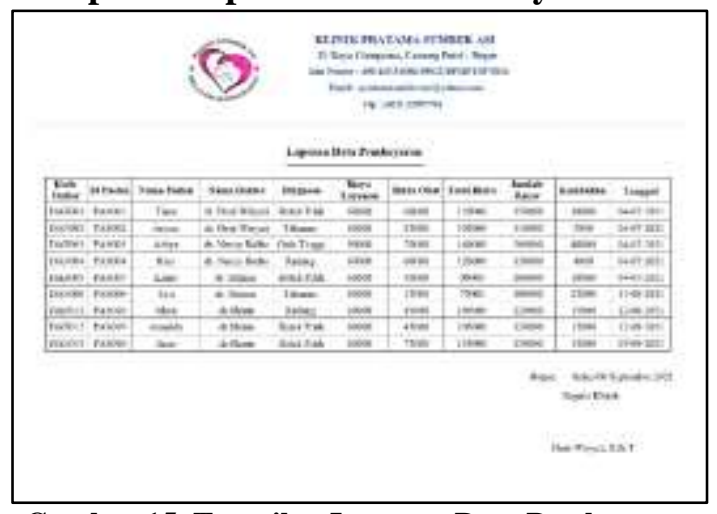

Gambar 15. Tampilan Laporan Data Pembayaran

Pada tampilan laporan pembayaran berisi kode daftar, id pasien, nama pasien, nama dokter, diagnosa, biaya layanan, biaya obat, total biaya, jumlah bayar, kembalian, dan tanggal. Laporan data pembayaran didapat dari data pembayaran yang tersimpan ke dalam database. 


\section{Tampilan Laporan Data Rekam Medis}

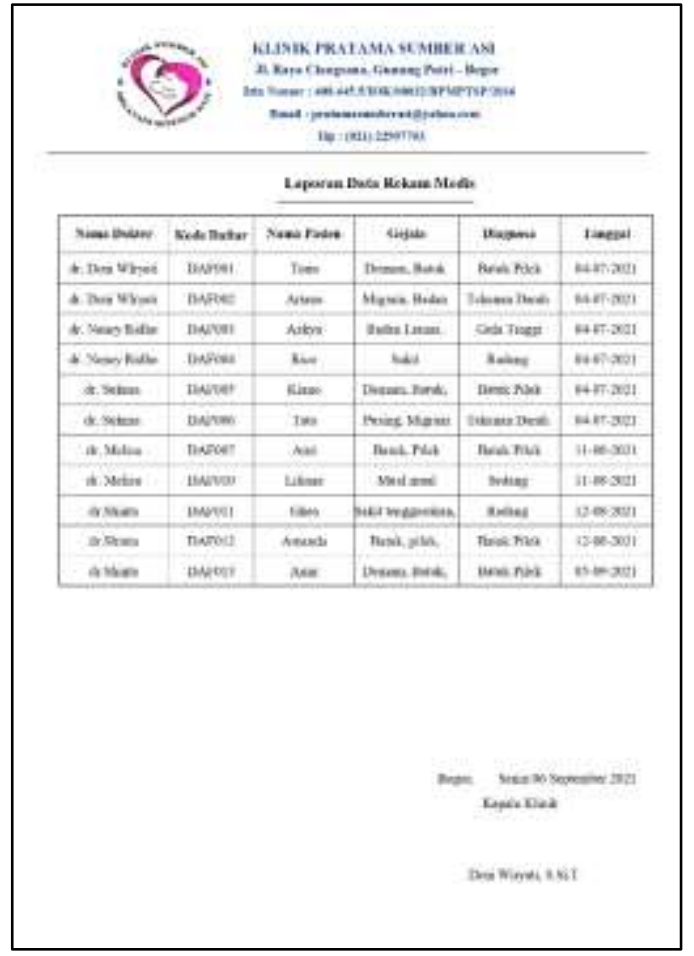

Gambar 16. Tampilan Laporan Data Rekam Medis

Pada tampilan laporan rekam medis berisi nama dokter, kode daftar, nama pasien, gejala, diagnosis dan tanggal. Laporan data rekam medis ini didapat dari data rekam medis yang tersimpan ke dalam database.

\section{SIMPULAN DAN SARAN}

Dengan dibuatnya sistem informasi pengolahan data pasien yang terkomputerisasi ini semua kegiatan yang berhubungan dengan olah data pasien dapat berjalan dengan baik dan lancar terutama saat melakukan penginputan data sehingga dapat terhindar dari kesalahan atau kekeliruan, dan saat hendak melakukan pencarian data dapat dilakukan dengan mudah, hanya tinggal memasukkan nama atau kode data yang hendak dicari.

Berdasarkan dengan sistem yang diusulkan yang sudah dibuat, agar dapat sesuai dengan tujuan dan dapat mengatasi permasalahan yang ada, maka berikut adalah saran yang dapat diberikan: Sistem informasi pengolahan data pasien ini dapat dikembangkan kembali dalam hal design maupun dalam penambahan field atau atribut dalam data, seperti data pasien, data obat, data dokter, data rekam medis, maupun data pembayaran agar dapat disesuaikan dengan kebutuhan klinik ke depannya.

\section{DAFTAR PUSTAKA}

Asrori, K., \& Nuryani, E. (2020). Sistem Informasi Administrasi Pembayaran Berbasis Aplikasi Web Studi Kasus pada SMK Al-Wahdah Citeras Sserang Banten. Jurnal Sistem Informasi Dan Informatika (Simika), 3(2), 16-26. https://doi.org/10.47080/simika.v3i2.97 5

D. Wijaya, Y., \& W. Astuti, M. (2019). Sistem Informasi Penjualan Tiket Wisata Berbasis Web Menggunakan Metode Waterfall. Prosiding Seminar Nasional Teknologi Informasi Dan Komunikasi (SENATIK), 2(1), 273-276.

Haryanto, \& Firmansyah, A. (2018). Sistem informasi pengolahan data pasien berbasis web pada Klinik Yadika Tangerang. Jurnal \& Penelitian Teknik Informatika, 2(April 2018).

Herliana, A., \& Rasyid, P. M. (2016). Sistem Informasi monitoring pengembangan software pada tahap development berbasis web. Jurnal Informatika, 3(1).

Prasetya, D. A. P., Irawan, P., \& Sokibi, P. (2020). Rancang Bangun Sistem Pengarsipan Surat Kedinasan Berbasis Web Menggunakan Framework Codeigniter. Jurnal Manajemen Informatika Dan Sistem Informasi, 3(2), 157-165.

Sukamto, \& Shalahuddin, M. (2015). Rekayasa Perangkat Lunak ( Terstruktur dan Berorientasi Objek) 2015. In Informatika Bandung.

Sutabri, T. (2012). Konsep sistem informasi. Penerbit Andi.

Syahputra, R. D., Susano, A., \& Alhidayatuddiniyah, A. (2021). Perancangan Sistem Informasi Pengelolaan Data Rekam Medis Pada Klinik Kharisma Berbasis Java. Semnas Ristek (Seminar Nasional Riset Dan Inovasi Teknologi), 5(1), 543-547. 